\title{
Iron Status of Multiple Transfused Sickle Cell Anaemia Patients Attending a Sickle Cell Clinic in Benin City, Nigeria
}

\author{
A. I. Ikusemoro1,2, N. K. D. Halim¹, O. A. Awodu' ${ }^{1}$, F. A. Ehiaghe ${ }^{2,4^{*}}$, E. M. Isoa ${ }^{3}$, I. J. Ehiaghe ${ }^{4}$ \\ ${ }^{1}$ Department of Haematology and Blood Transfusion,University of Benin Teaching Hospital, Benin City, Nigeria \\ ${ }^{2}$ Department of Hematology, College of Health Sciences, Igbinedion University Okada, Okada, Nigeria \\ ${ }^{3}$ Department of Hematology and Blood Transfusion, Irrua Specialist Teaching Hospital, Irrua, Nigeria \\ ${ }^{4}$ Department of Medical Laboratory Science, Nnamdi Azikiwe University, Awka, Nigeria \\ Email: ${ }^{*}$ fredleo2547@yahoo.com
}

Received 17 December 2013; revised 15 January 2014; accepted 22 January 2014

Copyright (C) 2014 by authors and Scientific Research Publishing Inc.

This work is licensed under the Creative Commons Attribution International License (CC BY).

http://creativecommons.org/licenses/by/4.0/

(c) (i) Open Access

\section{Abstract}

This study was aimed at evaluating the iron status of multiple blood transfused sickle cell anaemia (SCA) patients in Benin City, Nigeria. A total of 86 subjects participated in the study, comprising of 30 multiple transfused SCA subjects, 30 of rarely transfused SCA subjects and 26 of age and sex matched healthy control subjects. Serum ferritin was determined by enzyme linked immuno sorbent assay technique. Serum iron and Total iron binding capacity was determined by spectrophometric method. The mean serum ferritin concentration was elevated in the sickle cell anaemia patients whose multiple transfusions (MT) are more than those who were rarely transfused (RT) as compared with the control groups $(p<0.001)$. There was a positive correlation between the serum ferritin and the number of units of blood transfused $(r=0.719, p=0.000)$. This study revealed that a high level of serum ferritin, percentage transferrin saturation and a reduction in total iron binding capacity were observed in sickle cell anaemia patients who received $\geq 3$ units of packed cells in one year.

\section{Keywords}

Sickle Cell Anaemia, Multiple Transfusions, Serum Ferritin, Enzyme Linked Immuno Sorbent Assay

\footnotetext{
"Corresponding author.
} 


\section{Introduction}

Sickle cell disease (SCD) refers to a group of disorders caused by autosomal recessive inheritance of a pair of abnormal haemoglobin genes, including the sickle cell gene. It is characterized by chronic hemolytic anaemia and acute episodic clinical events called crisis [1]. Vaso-occlusive (painful) crisis is the most common, and other crises are acute hemolytic crisis, sequestration crisis and aplastic crisis [2]. The shortened life span of the sickle red cell coupled with other clinical complication often necessitates frequent blood transfusion in order to maintain a manageable haematocrit [3] [4]. The sickling factors that precipitate the occurrence of sickle cell crisis may be affected by multiple factors such as local tissue hypoxia, dehydration, infections, acidosis, stress and cold. In tropical Africa, malaria is the most common cause of anaemia and vaso-occlusive crisis [5]. High levels of fetal haemoglobin are known to ameliorate the severity and incidence of sickle cell crisis and other complications of the disease [6]. This study was aimed at evaluating the iron status of multiple blood transfused sickle cell anaemia patients in Benin City, Nigeria.

\section{Materials and Methods}

\subsection{Study Area}

The study area was carried out at the University of Benin Teaching Hospital, Benin City. It is a tertiary hospital that is concerned with the management of patients.

\section{A) Subjects \\ Sample size}

The sample size was obtained using this formula [7].

$\mathrm{N}=\mathrm{Z}^{2} \times \mathrm{P}(1-\mathrm{P}) / \mathrm{d}^{2}$

where:

$\mathrm{N}=$ Minimum sample Size

$\mathrm{D}=$ Desired level of significance $(0.05)$

$\mathrm{Z}=$ Confidence interval (1.96)

$\mathrm{P}=$ Prevalence rate $(2 \%-3 \%)$ [8]

\section{B) Subjects}

A total of 86 subjects participated in the study, comprising of 30 multiple transfused SCA subjects, 30 of rarely transfused SCA subjects and 26 of age and sex matched healthy control subjects. Ethical approval for this study was obtained from the hospital Ethics committee and informed consent was obtained from the test groups and the control groups.

\subsection{Inclusion Criteria}

Subjects confirmed to be sickle cell patients by haemoglobin electrophoresis who selected for this study. A history of blood transfusion was confirmed by checking through their case notes.

\subsection{Exclusion Criteria}

The following subjects were excluded from the study:

1. Sickle cell patients who were pregnant.

2. Heterozygous sickle cell disease (HBSC, HBSE).

\subsection{Problems Encountered}

There was a problem with recollection of information especially units of blood received by the patients. This was minimized by carefully going through the case notes.

\section{Blood Sample Collection}

$5 \mathrm{ml}$ of venous bloods were taken from the antecubital vein by venapuncture. It was transfer into an anticoagulant free test tube and allows to cloth and subsequently centrifuge at $750 \times \mathrm{g}$ from 15 minutes to obtain serum. The serum was immediately aliquoted into Eppendorf and stored at $-20^{\circ} \mathrm{C}$. 


\subsection{Assessment of Iron Status}

\subsubsection{Serum Ferritin}

Enzyme linked immunosorbent assay method used $0.05 \mathrm{ml}$ of fresh unhaemolysed serum was added to each of the wells and left overnight at $4^{\circ} \mathrm{C}$. The wells were washed three times with wash solution. Then $0.2 \mathrm{ml}$ of a substrate (chromogen) was added to the wells incubated for $30 \mathrm{~min} .0 .05 \mathrm{ml}$ of hydrochloric acid was added to each well to stop the reaction. The absorbance was read using a microplate reader at $450 \mathrm{~nm}$. The colour change is proportional to the amount of ferritin in serum [9].

\subsubsection{Serum Iron}

$2.5 \mathrm{ml}$ of an acidic buffer containing hydroxylamine was to four properly labeled test tubes blank, standard, test and control containing $0.5 \mathrm{ml}$ of fresh unhaemolysed serum. This addition caused a reduction the $\mathrm{Fe}^{3+}$ to $\mathrm{Fe}^{2+}$. $0.05 \mathrm{ml}$ of a chromogenic agent was then added which formed a highly colored $\mathrm{Fe}^{2+}$-complex that was measured spectrophotometrically at $560 \mathrm{~nm}$ [9].

\subsubsection{Total Iron Binding Capacity}

Unsaturated iron binding capacity (UIBC) was determined by adding excess $\mathrm{fe}^{2+}$ to serum so that they bind to the unsaturated iron binding sites on transferrin. The excess $\mathrm{fe}^{2+}$ was reacted with ferrozine to form a colour complex which was measured spectrophotometrically [9].

\subsubsection{Percentage Transferrin Saturation}

The Transferrin saturation is the ratio of the serum iron concentration and the TIBC expressed as a percentage.

\section{Analysis of Data}

All results were presented as mean \pm standard deviation and analyzed using one way analysis of variance (ANOVA) and Turkey-Kramer Multiple comparison test using SPSS-18.0 statistical program. P values $\leq 0.05$ were considered significant.

\section{Results}

Table 1: The Mean \pm Standard Deviation of serum iron concentration, serum ferritin concentration and percentage transferrin saturation was higher in the multi-transfused group as compared to the control subjects, showing a significant difference $(\mathrm{p}<0.001)$. Similarly, the mean total iron binding capacity was significantly higher in the control subjects as compared to the multi-transfused subjects $(\mathrm{p}<0.001)$.

Table 2: The Mean \pm standard Deviation of serum iron concentration, serum ferritin concentration and percentage transferrin saturation between the rarely transfused subjects and the control subjects, there were no statistically significant differences in their mean values $(\mathrm{p}>0.05)$. However, the mean total iron binding capacity was higher in the control subjects than in the rarely transfused subjects $(\mathrm{p}<0.001)$.

Table 3: The Mean \pm Standard Deviation of serum iron concentration, serum ferritin concentration and percentage transferrin saturation were higher in the multi-transfused subjects than that observed in the rarely transfused subjects $(\mathrm{p}<0.001)$.

Figure 1: Depicts a regression analysis graph of serum ferritin and number of units of blood transfused over a five year period. A linear relationship was observed between the number of units of blood transfused and the serum ferritin level in the multi-transfused subjects. Indicating that serum ferritin rises with increasing transfusion requirements.

Table 1. The mean \pm standard deviation of iron status in multi-transfused subjects and controls.

\begin{tabular}{cccc}
\hline PARAMETERS & MULTI-TRANSFUSED $\mathbf{n}=\mathbf{3 0}$ & CONTROL $\mathbf{n}=\mathbf{2 6}$ & P value \\
\hline Serum Iron (ug/dl) & $152.8 \pm 23.4$ & $95.1 \pm 26.7$ & $<0.001$ \\
Serum Ferritin (ug/dl) & $396.4 \pm 130.8$ & $107.2 \pm 13.0$ & $<0.001$ \\
Total Iron Binding Capacity (ug/dl) & $280.2 \pm 37.9$ & $366.8 \pm 76.4$ & $<0.001$ \\
\% Transferrin saturation & $55.2 \pm 9.9$ & $26.8 \pm 8.8$ & $<0.001$ \\
\hline
\end{tabular}


Table 2. The mean \pm standard deviation of iron status in rarely transfused subjects and controls.

\begin{tabular}{cccc}
\hline PARAMETERS & RARELY TRANSFUSED $\mathbf{n}=\mathbf{3 0}$ & CONTROL $\mathbf{n}=\mathbf{2 6}$ & P value \\
\hline Serum Iron (ug/dl) & $96.5 \pm 22.2$ & $95.1 \pm 26.7$ & 0.84 \\
Serum Ferritin (ug/dl) & $124.9 \pm 67.2$ & $107.2 \pm 13.0$ & 0.052 \\
Total Iron Binding Capacity (ug/dl) & $248.1 \pm 57.0$ & $366.8 \pm 76.4$ & $<0.001$ \\
\% Transferrin saturation & $31.7 \pm 11.0$ & $26.8 \pm 8.8$ & 0.064 \\
\hline
\end{tabular}

Table 3. The mean \pm standard deviation of iron status in multi-transfused and rarely transfused subjects.

\begin{tabular}{cccc}
\hline PARAMETERS & MULTI- TRANSFUSED $\mathbf{n}=\mathbf{3 0}$ & RARELY TRANSFUSED $\mathbf{n}=\mathbf{3 0}$ & P value \\
\hline Serum Iron (ug/dl) & $152.8 \pm 23.4$ & $96.5 \pm 22.2$ & $<0.001$ \\
Serum Ferritin (ug/d) & $396.4 \pm 130.8$ & $124.9 \pm 67.2$ & $<0.001$ \\
Total Iron Binding Capacity (ug/dl) & $280.2 \pm 37.9$ & $248.1 \pm 57.0$ & 0.06 \\
\% Transferrin saturation & $55.2 \pm 9.9$ & $31.7 \pm 11.0$ & $<0.001$ \\
\hline
\end{tabular}

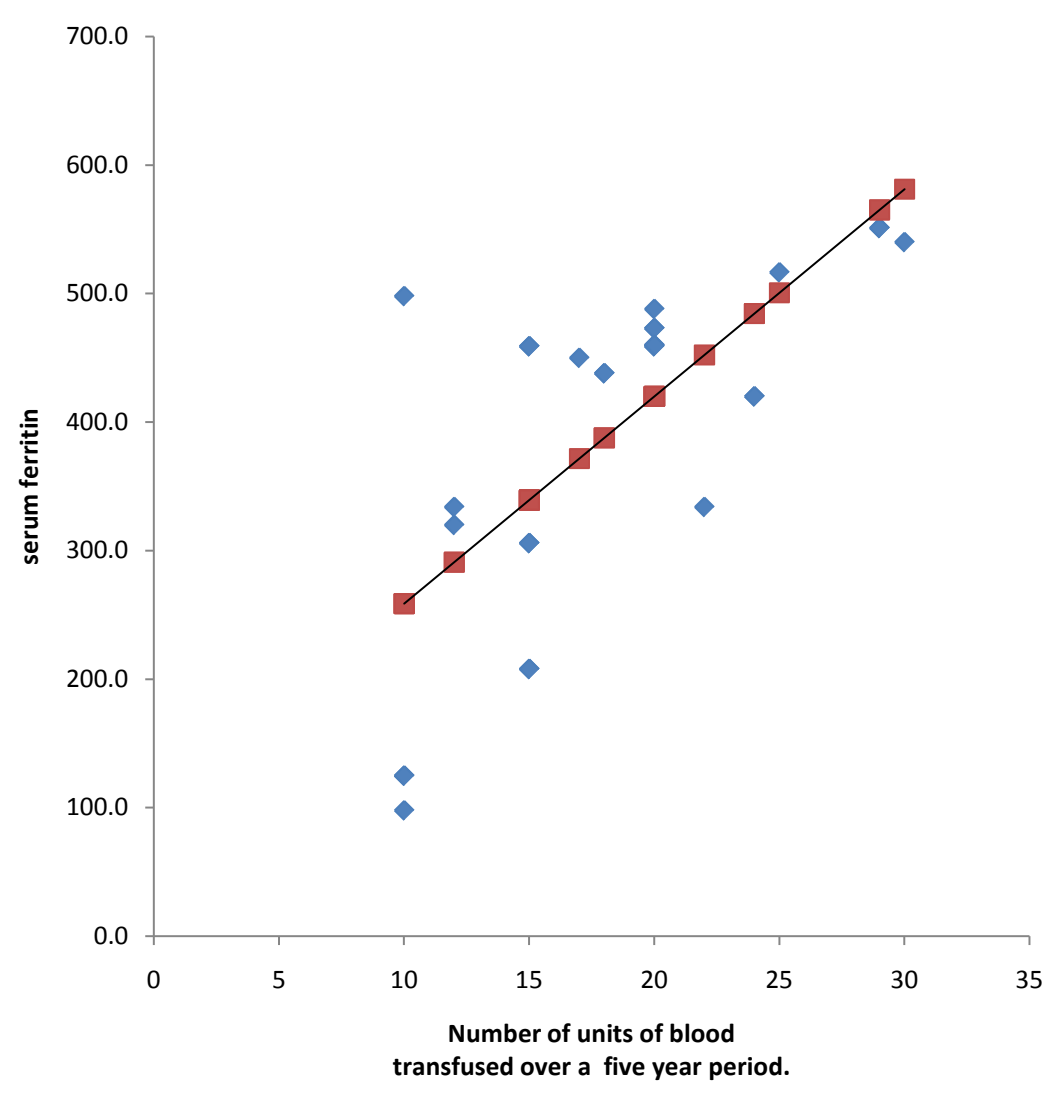

Figure 1. Scatter gram of serum ferritin and Number of units of blood transfused.

Table 3 Shows correlation coefficient for the number of units of blood transfused (POB) and the iron status of multi-transfused patients. There was a positive correlation between the serum ferritin and the number of units of blood transfused $(r=0.719, p=0.000)$. A similar trend was also observed between the percentage transferrin saturation and serum ferritin $(r=0.473, p=0.002)$, percentage of transferring saturation and number of units of blood transfused $(r=0.407, p=0.026$ ). whilst the total iron binding capacity show a negative correlation between number of units of and serum ferritin $(r=0.473, p=0.002)$, percentage of transferring saturation and 
number of units of blood transfused $(r=0.407, p=0.026)$. whilst the total iron binding capacity show a negative correlation between number of units of blood transfused $(r=-0.251, p=0.180)$, serum ferritin $(r=-0.091, p=$ $0.663)$ and percentage transferrin saturation $(r=-0.471, \mathrm{p}=0.009)$.

\section{Discussion}

Sickle cell anaemia is a chronic debilitating hematological condition often requiring frequent blood transfusions in order to maintain a manageable haematocrit and also increase the possibility of eliminating the most complications of the disease, which includes alloimmunization, iron overload and transfusion of microbial agents which are significant risk factors that limit the use of blood transfusions in the management of severe complications. In this study, the mean serum ferritin concentration was elevated in the sickle cell anaemia patients who had multiple blood transfusions $\geq 3$ units of blood per year than those who were rarely transfused (RT) as compared with the control groups, ( $<$ 0.001) Tables 1-3. The mean serum ferritin level was found to be greater than $300 \mu \mathrm{g} / \mathrm{dl}$ in the multi-transfused (MT) patients. This is not surprising because as iron accumulates, the serum ferritin concentration rises and values above $300 \mu \mathrm{g} / \mathrm{dl}$ signify an increase in iron stores. This agrees with these finding. Elevated levels of serum ferritin are seen in hyper transfused sickle cell anaemia patients 10 . The mean total iron binding capacity (TIBC) in this study was found to be $280.2 \mu \mathrm{g} / \mathrm{dl} \pm 37.9 \mu \mathrm{g} / \mathrm{dl}$ for the multi-transfused SCA patients. Although this is within the expected range (200 - $400 \mu \mathrm{g} / \mathrm{dl})$, it is still low when compared with the levels of $366.8 \mu \mathrm{g} / \mathrm{dl} \pm 76.4 \mu \mathrm{g} / \mathrm{dl}$ for the control subjects. This is not surprising because an increase in iron stores in the multi-transfused subjects reflects the amount of transferrin in circulation. It is often decreased with an increase in iron stores. The mean total iron binding capacity observed in the rarely transfused $(248.1 \mu \mathrm{g} / \mathrm{dl} \pm 57.0 \mu \mathrm{g} / \mathrm{dl})$ is lower than that of the control subjects $(366.8 \mu \mathrm{g} / \mathrm{dl} \pm 76.4 \mu \mathrm{g} / \mathrm{dl})$ despite the fact that there is no significant difference in their mean serum iron concentrations $(96.5 \mu \mathrm{g} / \mathrm{dl} \pm 22.2 \mu \mathrm{g} / \mathrm{dl}$ and 95.1 $\mu \mathrm{g} / \mathrm{dl} \pm 26.7 \mu / \mathrm{dl}$ ) respectively, it shows that there is a low serum iron level together with a reduction in total iron binding capacity in the rarely transfused SCA subjects which are consistent with the findings in anaemia of chronic inflammation. It is not unexpected as sickle cell anaemia patients are predisposed to recurrent infections. The early stages of iron accumulation are detectable by an increase in serum iron, a decreased total iron binding capacity and increased transferrin saturation [10].

This study shows a positive correlation between serum ferritin and number of units of blood transfused $(\mathrm{r}=$ 0.719, $\mathrm{p}=0.000$ ) as seen in Table 4 and Figure 1, this is in accordance with these findings. The ferritin values correlate with the number of blood transfused [11]. A linear increase in serum ferritin level is seen in cumulative transfusion cases [12]. A higher mean serum ferritin values in sickle cell anaemia patients who had multiple transfusions is established [13]-[15]. Blood transfusion is not the only contributory factor to increase in serum ferritin levels [16]-[18]. However, in health serum ferritin concentration correlates with iron stores [19]-[21], ferritin synthesis is influenced by factors such as inflammatory conditions where ferritin behaves as an acute phase reactant [20].

The percentage of Transferrin saturation found in the multi-transfused sickle cell anaemia patients was greater than $50 \%$ with a mean value of $55.2 \%$, the transferrin saturation is the ratio of the serum iron concentration and the total iron binding capacity expressed in percentage. The finding in this study is not unexpected because ele-

Table 4. Correlation between Numbers of units of blood transfused and Iron Status in Multi-transfused subjects.

\begin{tabular}{cccccc}
\hline & POB & SI & SF & TIBC & STR \\
\hline POB r & 1 & 0.227 & 0.719 & -0.251 & 0.407 \\
P value & & 0.228 & 0.000 & 0.180 & 0.026 \\
SI r & 0.227 & 1 & 0.420 & 0.317 & 0.682 \\
P value & 0.228 & & 0.021 & 0.087 & 0.000 \\
SF r & 0.719 & 0.420 & & -0.091 & 0.473 \\
P value & 0.000 & 0.021 & 0.633 & 0.008 \\
TIBC r & -0.251 & 0.317 & -0.091 & 1 & -0.471 \\
P value & 0.180 & 0.087 & 0.633 & -0.471 & 0.009 \\
STR r & 0.407 & 0.682 & 0.473 & 0.009 & 1 \\
P value & 0.026 & 0.000 & 0.002 & \\
\hline
\end{tabular}

Key: r-Pearson Correlation Co-efficient, POB—Number of units of blood transfuse, SI—Serum iron. SF—Serum ferritin, TIBC—Total iron binding capacity, STR - Percentage serum transferrin saturation. 
vated transferrin saturation is indicative of an early detection of iron overload, this in line with these finding. One third of the adult sickle cell disease patients on regular blood transfusions had percentage transferrin saturation greater than $50 \%$ [22].

\section{Conclusion and Recommendations}

This study revealed that a high level of serum ferritin, percentage transferrin saturation and a reduction in total iron binding capacity were observed in sickle cell anaemia patients who received $3 \geq$ units of packed cells per year, suggesting an increase in iron stores and are at risk of developing iron overload. Serum ferritin should be routinely assayed for patients with HBSS requiring frequent blood transfusions for early detection of iron overload and the need for iron chelating agent to be incorporation into the management of sickle cell anaemia patients, particularly those requiring multiple blood transfusions is advocated.

\section{References}

[1] Akinyanju, O.O. (1989) A Profile of Sickle Cell Disease in Nigeria. Annals of the New York Academy of Sciences, 565, 126-136. http://dx.doi.org/10.1111/j.1749-6632.1989.tb24159.x

[2] Edelstein, S.J. (1981) Molecular Topology in Crystals and Fibers of Hemoglobin S. Journal of Molecular Biology, 150, 557-575. http://dx.doi.org/10.1016/0022-2836(81)90381-8

[3] Walter, P.B., Harmatz, P. and Vishinski, E. (2009) Iron Metabolism and Iron Chelation in Sickle Cell Disease. Acta Hematological, 122, 174-183. http://dx.doi.org/10.1159/000243802

[4] Pippard, M., Johnson, D., Callender, S. and Finch, C. (1982) Ferrioxamine Excretion in Iron Loaded Man. Blood, 60, 286-294.

[5] Ohene-Frempong, K. and Nkrumah, F.K. (1994) Sickle Cell Disease in Africa. In: Embury, S.H., Hebbel, R.P., Mohandas, N., Eds., Sickle Cell Disease: Basic Principles and Clinical Practice, Raven Press Ltd., New York, 423-435.

[6] Platt, O., Thorington, M.S. and Brambilla, D.J. (1991) Pain in Sickle Cell Disease-Rates and Risk Factors. The New England Journal of Medicine, 325, 11-16. http://dx.doi.org/10.1056/NEJM199107043250103

[7] Naing, L., Winn, T. and Rush, B.N. (2006) Practical Issues in Calculating the Sample Size for Prevalence Studies. Archives of Orofacial Sciences, 1, 9-14.

[8] Tietz, N.W. (1984) Fundamentals of Clinical Chemistry. W.B. Saunders, Philadelphia.

[9] Davies, S., Henthorn, J. and Brozovic, M. (1983) Iron Deficiency in Sickle Cell Anaemia. Journal of Clinical Pathology, 36, 1012-1015. http://dx.doi.org/10.1136/jcp.36.9.1012

[10] Mahoney, B.S., Ambruso, D.R. and Githens, J.H. (1978) Iron Studies in Sickle Cell Anaemia. Journal of Pediatrics, 93, 1070.

[11] Serjeant, G.R. (1992) Sickle Cell Disease. Oxford University Press, Oxford.

[12] Peterson, C.M., Crazino, J.H. and Ciutiis, A. (1975) Iron Metabolism, Sickle cell Disease and Response to Cyanate. Blood, 46, 583-590.

[13] Hussain, M.A.M., Davis, L.R., Laulicht, M. and Hoffbrand, A.V. (1978) Value of Serum Ferritin Estimation in Sickle Cell Anaemia. Archives of Disease in Childhood, 53, 319-321.

[14] Oluboyede, O.A., Usanga, E.A., Lukambi, F.A. and Ajayi, O.A. (1996) Evaluation of Serum Ferritin Levels and Other Hematological Parameters in a Nigerian Population. Journal of the National Medical Association, 75, 885-889.

[15] Aken'Ova, Y.A., Adaefai, C. and Okunade, M. (1997) Ferritin and Serum Iron Levels in Adult Patients with Sickle Cell Anaemia in Ibadan, Nigeria. African Journal of Medicine \& Medical Sciences, 26, 39-41.

[16] Hoffbrand, A.V., Daniel, C. and Edward, G.D. (2004) Sickle Cell Disease, Postgraduate Haematology. 5th Edition, Blackwell Publishing, Oxford.

[17] Powars, D.R. (1975) Natural History of Sickle Cell Disease-The First Ten Years. Seminars in Hematology, 12, 267-285

[18] Biergegard, G., Hogman, C., Killander, A., Levander, H., Simsson, B. and Wide, L. (1977). Serum Ferritin and Erythrocyte 2, 3-DPG during Phlebotomy and Iron Treatment. Scandinavian Journal of Haematology, 19, 327-33. http://dx.doi.org/10.1111/j.1600-0609.1977.tb01482.x

[19] Cook, J.D. and Finch, C.A. (1979) Assessing the Iron Status of a Population. The American Journal of Clinical Nutrition, 32, 2115-2119.

[20] Legget, B.A., Brown, N.N., Bryant, S.J., Dullock, L. and Powell, L.W. (1990) Factors Affecting the Concentration of 
Ferritin in the Serum of Healthy Australian Population. Clinical Chemistry, 36, 1350-1355.

[21] Cardeza, T.D. (2001) Foundation for Hematologic Research Philadelphia USA. Seminars in Hematology, 38, 30-36.

[22] Ballas, S.K. (2001) Iron Overload Is a Determinant of Morbidity and Mortality in Adult Patients with Sickle Cell Disease. Seminars in Hematology, 38, 30-36. http://dx.doi.org/10.1016/S0037-1963(01)90058-7 